Journal of English Language Teaching

UNNES

\title{
The analysis of teachers' professional competence in utilizing information and communication technology
}

\author{
Noven Aquilla Abkarin ${ }^{\bowtie}$
}

English Department, Universitas Negeri Semarang, Indonesia

\begin{tabular}{l} 
Article Info \\
\hline Article History: \\
Received in 26 \\
August 2020 \\
Approved in 29 \\
November 2020 \\
Published in 28 July \\
2021 \\
\hline \\
Keywords: Teachers' \\
professional competence; \\
Information and \\
Communication \\
Technology; supporting \\
and inhibiting factors
\end{tabular}

\begin{abstract}
This study is about the utilization of ICT in classroom learning to develop teacher's professional competence. Nowadays, COVID-19 pandemic has already spread around the world. It brings bad impacts on many sectors, especially the education sector. Based on the issue, this study aims to investigate teacher's familiarity with the use of ICT, to find out teachers' professional competence in utilizing ICT in classroom learning, and to obtain supporting and inhibiting factors of teachers' professional competence in utilizing ICT. A qualitative approach was used as a method of this study. Data collection was conducted by distributing questionnaires, carrying out structured interviews, and documentation addressed to ten respondents consisting of English teachers from three schools in Wonosobo, Central Java, Indonesia. This study reveals that ten teachers were familiar with using ICT in classroom learning. They claimed that the use of ICT can help their works in the teaching and learning process. Second, the teacher's professional competence can improve ICT utilization in teaching and learning classrooms. The use of ICT also can improve teachers' professional competence because ICT usage is easier and more effective to deliver materials. Third, some supporting factors of the use of ICT were found in this study. They were making teaching and learning process easier, increasing students' motivation, and improving teachers' professional competence. The use of ICT also could make teachers easily take part in this digital era.
\end{abstract}




\section{INTRODUCTION}

In the $21^{\text {st }}$ century, Indonesia is able to pursue the technological developments. Changes and developments are also happening in the world of education, including education and teaching English (Priyatmojo et al., 2017). It has been proven by the rise of the use of Information and Communication Technology in the classroom activity. Information and Communication Technology is modern renewal which can be applied in education. Fu (2013) stated that Information and Communication Technology (ICT) is electronic devices that are mostly used in education sector nowadays such as computers, televisions, radios, Internet, projectors, and others. In Indonesia, ICT is often related to current development. Therefore, education minister has revised some curriculum from KTSP 2006 into the newest one, called revised K-13. In this case, the government has policy in increasing the quality of education. In ICT development, it brings many advantages in education field. 2013 Curriculum is Competence-based curriculum that requires all of the activities as studentcenter. It means that all the classroom activities in teaching and learning English require that students have to be active. Hence, the teacher should use ICT for the effective classroom learning.

Nowadays, COVID-19 pandemic has already spread around the world. It brings bad impacts on many sectors, especially the education sector. According to UNESCO (2020, in Di Perto et al., 2020) showed that at the end of April 2020, educational sectors immobilize in 186 countries, affecting approximately $74 \%$ of the total enrolled learners around the world. It has devastated teachers, students, schools, and the education system.Teachers as a role model for students, the teachers' performance are noticed by the students. Therefore, teachers have come to realize that every meaningful improvement that students receive depends on the quality of teaching.

A good teacher must have good competences. According to the Act Number 14 Year 2005, there are four competences that teachers must have including personality, pedagogy, social, and professional (Lao et al., 2017). First, personality competence is one of the abilities that teacher must have. Pahrudin et al. (2016) stated that it reflects a good personality e.g. wise, kind, maturity, etc., being a role model for students, and also having good character. Second, pedagogy competence is the teachers' ability to design and implement the learning strategy. Third, social competence is teachers' ability to do interaction with their students, colleagues, students' parents and society (Pahrudin et al., 2016). Fourth, professional competence is teachers' ability that they have to master learning material deeply, curriculum, management classroom, lesson plan, etc. (Pahrudin et al., 2016).

In addition, this study focused on the ICT utilization teachers needed to develop their professional competence. This study aims to find how teacher's familiarity on the use of ICT in classroom learning is, how teachers' professional competence in utilizing Information and Communication Technology in classroom learning is and what supporting and inhibiting factors of teachers' profession competence in utilizing ICT in classroom learning are.

Adhini (2018) conducted a study entitled teachers' perception of social media in developing pedagogical competence. This study investigated teachers' perceptions of using social media to enhance pedagogical competence. The objectives of the study were to explore the teachers' familiarity on the use of social media, to explain the teachers' frequency in using social media and to analyze teachers' perception of using social media in developing their pedagogical competence. This is related to the writer's research in using the part of ICT in the teaching and learning process. This study attempted to find out teachers' frequency in using social media and analyze teachers' perceptions of using social media in developing their pedagogical competence. It is a bit different from the writer's research because this research only focused on the use of social media in learning activities whereas the writer's research will use information and communication technology generally to find out English teachers' factors in mastering ICT.

Next study was conducted by Akinwamide \& Felicia (2018) entitled Professional Updates for Language Teachers in Digitally Infected Clime: The ICT Utilization Sensibility. The objectives of this study were to find out the training or retraining of the ICT utilization for the English teachers and whether there was a provision to develop human capacity in the learning process. This study used descriptive survey design. There were 571 English teachers (all English teachers) in a senior secondary school in Ekiti State. They were collected as a population. In selecting the sample, a multistage random sampling technique was employed by the writer. In collecting the data, a questionnaire was used by the writer. Based on the finding of the research, this study indicated that there was no significant relationship between the provision that enacts human capacity for ICT utilization. The teachers had not received training to develop their skills in utilizing ICT. This study related to the writer's 
research because it explained the teachers' sensibility in the use of Information and Communication Technology in the digital era. This study was conducted in Nigeria with a lot of problems against the integrity of the profession. On the other hand, the difference is the writer wants to know how ICT utilization in improving teacher's professional competence.

Al-Munawwarah, (2014) conducted a study entitled Teachers' Perception on the Use of ICT in Indonesia EFL Learning Context. This study investigated teachers' perceptions in implementing the use of ICT in the EFL learning process. This study was almost similar to the writer's study because this study implemented ICT in the teaching and learning process and found out the advantages and disadvantages of the use of ICT. The writer also emphasized English teachers' professional competence in using ICT. This study will be useful for one of the references to support the research.

\section{METHODS}

This study used qualitative research method. It tended to explicate the analysis of research problems in this study. According to Creswell (2014), qualitative method has different approach to investigate the study than quantitative method. Qualitative method relied on data analysis such as text and image data. In collecting the data, I used three types of data collections. There was questionnaire, structured interview and documentation. The research instruments of this study were developed to solve the research problem of this study. A questionnaire used to find out teachers' performance in the use of ICT in classroom. Therefore, a structured interview involved open-ended questions and it gained to find out supporting and inhibiting factors that teachers faced in the learning activities by using ICT. Documentation used to support interview process. The subject of the study was 10 English teachers who teach in senior high school and vocational high school in Wonosobo regency. There were the English teachers who have professional competence in teaching and learning process especially in the use of ICT.

This study used three data collection; questionnaire, interview, and documentation. The aim of providing questionnaire is to find out how English teachers' professional competence in utilizing ICT is, supporting and inhibiting factors of English teacher has to use ICT in classroom learning, and teachers' perception of the use of ICT to develop their professional competence. The questionnaire was distributed to investigate general opinion of the participants toward the ICT utilization in classroom and the ICT utilization to support teachers' professional competence. The purpose of this study was to get detail information about teachers' perspective in the use ICT in mastering professional competence. The result of the ICT utilization in classroom learning can be explored by calculating integrated score. The structured interview was to investigate teacher's familiarity in the use of ICT and supporting and inhibiting factors in the use of ICT. Structured interview was distributed to analyze teacher's familiarity on the use of ICT and analyze twelve dimensions and items of supporting and inhibiting factors in the ICT Utilization. The general opinion was about teachers' perception in the ICT Utilization to find supporting and inhibiting factors. Lastly, documentation was used to support questionnaire and interview process.

The data analysis had conducted during the data collection take place and after finish the data collection. There were three activities in analyzing data. Data reduction was data that has been summarized and chosen into the main point. Reduced data gave description easily, and makes the researcher easier in collecting data. After data reduction, the data was displayed in form of graphics, table, chard, pictogram, etc. Data display also can make the researcher easier to understand what's happening and to do something-further analysis. The last step of analysis data was conclusions. The conclusion of qualitative research was new findings. The finding can be formed a description of an object that was originally still in doubt so that after doing research, it became clear one.

\section{FINDINGS AND DISCUSSION}

This study showed the findings of the research. This research finding discussed research problems. The research problems were how teachers' familiarity on the use ICT in classroom learning is, how the teachers' professional competence in utilizing ICT in classroom learning is, and what supporting and inhibiting factors of teachers' professional competence in utilizing ICT are.

\section{Respondents' familiarity on the use of ICT in classroom}

Based on the result of respondents' familiarity on the use of ICT in classroom learning, I found three indicators in Table 1. Indicator No. 1 was used to present information about teachers' understanding 
of ICT. In this statement, Option A was social media's meaning. Option B was ICT's meaning (correct answer). Then, Option C was internet's meaning.

Indicator no. 2 was used to present information about ICT classification. In this statement, option A was social media (e.g. Whatsapp, Line, Facebook, Skype, Twitter, and My Space). Option B was accessing internet (e.g. Drive, Elena, Google Classroom, Blog, and Wordpress). Option C was using Computer or Laptop.

Indicator no. 3 was used to present information about teacher's frequency in the use of ICT in classroom. In this statement, there were three options; (a) every meeting, (b) once a week, and (c) once a month.

Indicator no. 4 was used to present information about teacher's readiness in using ICT in classroom learning. In this statement, there were three options; (a) Not ready (b) Ready without preparation (c) Ready with preparation.

Indicator no. 5 was used to present information about the use of ICT can support teachers' professional competence. In this statement, there were three option; (a) Yes, always (b) Yes, sometimes (c) Not at all.

Table 1. Teachers' familiarity in the ICT Utilization

\begin{tabular}{|c|c|c|c|c|c|c|c|}
\hline \multirow{3}{*}{ No. } & \multirow{3}{*}{ Indicator } & \multicolumn{6}{|c|}{ Category } \\
\hline & & \multicolumn{2}{|c|}{$\mathbf{A}$} & \multicolumn{2}{|c|}{ B } & \multicolumn{2}{|c|}{ C } \\
\hline & & Frequency & Precentage & Frequency & Precentage & Frequency & Precentage \\
\hline 1 & ICT Understanding & 60 & $60 \%$ & 10 & $10 \%$ & 30 & $30 \%$ \\
\hline 2 & ICT Classification & 26 & $26 \%$ & 37 & $37 \%$ & 37 & $37 \%$ \\
\hline 3 & $\begin{array}{l}\text { Frequency of the use } \\
\text { ICT }\end{array}$ & 20 & $20 \%$ & 50 & $50 \%$ & 30 & $30 \%$ \\
\hline 4 & $\begin{array}{l}\text { Teachers' readiness in } \\
\text { using ICT }\end{array}$ & 20 & $20 \%$ & 30 & $30 \%$ & 50 & $50 \%$ \\
\hline
\end{tabular}

The utilization of ICT in classroom to support teachers' professional

The questionnaire was distributed to investigate general opinions of the participants toward the ICT utilization in classrooms and the ICT utilization to support teachers' professional competence. The purpose of this study was to get detail information about teachers' perspective in the use ICT in mastering professional competence. The general opinion about utilization ICT in classroom learning was presented in Table 1 while the ICT utilization to support teachers' professional competence was presented in Table 2.

Table 2. The ICT Utilization in the classroom learning

\begin{tabular}{|c|c|c|c|c|c|c|}
\hline \multirow{2}{*}{ No. } & \multirow{2}{*}{ Statements } & \multicolumn{5}{|c|}{ Scale } \\
\hline & & 5 & 4 & 3 & 2 & 1 \\
\hline 1 & $\begin{array}{l}\text { I always utilize ICT services to look up teaching materials (news, article, video, } \\
\text { etc.). }\end{array}$ & 3 & 6 & 1 & 0 & 0 \\
\hline 2 & I think using ICT makes effective use of class time. & 1 & 8 & 1 & 0 & 0 \\
\hline 3 & I think using ICT makes me more productive as a teacher. & 3 & 6 & 0 & 1 & 0 \\
\hline 4 & I think that I can use ICT in class activities more effectively day by day. & 0 & 9 & 1 & 0 & 0 \\
\hline 5 & $\begin{array}{l}\text { I believe that ICT services like internet, computer, laptop, socialmedia will make } \\
\text { communication with my students easier. }\end{array}$ & 6 & 4 & 0 & 0 & 0 \\
\hline 6 & $\begin{array}{l}\text { I think that usage of instructional ICT makes it easier to prepare course } \\
\text { materials (assignments, handouts, etc.). }\end{array}$ & 4 & 6 & 0 & 0 & 0 \\
\hline 7 & $\begin{array}{l}\text { I can handle different learning preferences of my students having different } \\
\text { learning styles by using instructional ICT. }\end{array}$ & 2 & 8 & 0 & 0 & 0 \\
\hline 8 & $\begin{array}{l}\text { I think that ICT media makes it easier to reach instructional resources in the } \\
\text { class. }\end{array}$ & 3 & 7 & 0 & 0 & 0 \\
\hline 9 & I think that using ICT will change pattern of learning and work activities. & 2 & 7 & 1 & 0 & 0 \\
\hline 10 & I feel that I must use ICT services during my classes. & 3 & 5 & 1 & 1 & 0 \\
\hline & $\begin{array}{c}\text { Total } \\
\text { Total in Percent } \\
\end{array}$ & $\begin{array}{c}27 \\
27 \%\end{array}$ & $\begin{array}{l}66 \\
66 \%\end{array}$ & $\begin{array}{c}5 \\
5 \%\end{array}$ & $\begin{array}{c}2 \\
2 \%\end{array}$ & $\begin{array}{c}\mathbf{0} \\
\mathbf{0} \%\end{array}$ \\
\hline
\end{tabular}


The result of the ICT utilization in classroom learning can be explored by calculating integrated score. Table 3 was presented each integrated score of item.

Table 3. Integrated Score for Each Respondent in the ICT Utilization in classroom learning statements

\begin{tabular}{clcc}
\hline No. & \multicolumn{1}{c}{ Statements } & $\begin{array}{c}\text { Integrated } \\
\text { Score }\end{array}$ & Percentage \\
\hline 1 & $\begin{array}{l}\text { I always utilize ICT services to look up teaching materials (news, article, } \\
\text { video, etc.). }\end{array}$ & 42 & $10,04 \%$ \\
2 & I think using ICT makes effective use of class time. & 40 & $9,56 \%$ \\
3 & I think using ICT makes me more productive as a teacher. & 41 & $9,80 \%$ \\
4 & I think that I can use ICT in class activities more effectively day by day. \\
5 & I believe that ICT services like internet, computer, laptop, social media \\
& will make communication with my students easier. & 39 & $9,33 \%$ \\
6 & 46 & $11,04 \%$ \\
I think that usage of instructional ICT makes it easier to prepare course & 44 & $10,52 \%$ \\
7 & materials (assignments, handouts, etc.). & $42 \%$ \\
& I can handle different learning preferences of my students having different \\
8 & I think that ICT media makes it easier to reach instructional resources in & 42 & $10,04 \%$ \\
& the class. & 43 & $10,28 \%$ \\
9 & I think that using ICT will change pattern of learning and work activities. & 41 & $9,80 \%$ \\
10 & I feel that I must use ICT services during my classes. & 40 & $9,56 \%$ \\
& $\quad$ Total & 418 & $100 \%$ \\
\hline
\end{tabular}

The result of the ICT utilization in classroom learning can be explored by calculating integrated score. Table 4 was presented each integrated score of items.

Table 4 Integrated Score for Each Respondent in the ICT Utilization in classroom learning statements

\begin{tabular}{|c|c|c|c|}
\hline No. & Statements & $\begin{array}{l}\text { Integrated } \\
\text { Score }\end{array}$ & Percentage \\
\hline 1 & $\begin{array}{l}\text { I always utilize ICT services to look up teaching materials (news, article, video, } \\
\text { etc.). }\end{array}$ & 42 & $10,04 \%$ \\
\hline 2 & I think using ICT makes effective use of class time. & 40 & $9,56 \%$ \\
\hline 3 & I think using ICT makes me more productive as a teacher. & 41 & $9,80 \%$ \\
\hline 4 & I think that I can use ICT in class activities more effectively day by day. & 39 & $9,33 \%$ \\
\hline 5 & $\begin{array}{l}\text { I believe that ICT services like internet, computer, laptop, social media will } \\
\text { make communication with my students easier. }\end{array}$ & 46 & $11,04 \%$ \\
\hline 6 & $\begin{array}{l}\text { I think that usage of instructional ICT makes it easier to prepare course } \\
\text { materials (assignments, handouts, etc.). }\end{array}$ & 44 & $10,52 \%$ \\
\hline 7 & $\begin{array}{l}\text { I can handle different learning preferences of my students having different } \\
\text { learning styles by using instructional ICT. }\end{array}$ & 42 & $10,04 \%$ \\
\hline 8 & $\begin{array}{l}\text { I think that ICT media makes it easier to reach instructional resources in the } \\
\text { class. }\end{array}$ & 43 & $10,28 \%$ \\
\hline 9 & I think that using ICT will change pattern of learning and work activities. & 41 & $9,80 \%$ \\
\hline \multirow[t]{2}{*}{10} & I feel that I must use ICT services during my classes. & 40 & $9,56 \%$ \\
\hline & Total & 418 & $100 \%$ \\
\hline
\end{tabular}

Based on the table, it can be concluded that the highest respondents' statement on the ICT utilization was teachers' belief on the ICT services like the Internet, computer, laptop, and social media will make communication with the students easier. In addition, the lowest statement of respondents' ICT utilization in classroom learning was teacher thinks that they can use ICT in class activities more effectively day by day. The following table presented the result of ICT Utilization in mastering teachers' professional competence. 
Table 5 ICT Utilization in Mastering Teachers' Professional Competence

\begin{tabular}{|c|c|c|c|c|c|c|}
\hline \multirow[b]{2}{*}{ No. } & \multirow{2}{*}{ Statements } & \multicolumn{5}{|c|}{ Scale } \\
\hline & & 5 & 4 & 3 & 2 & 1 \\
\hline 1 & The use of ICT will improve teacher' professional competence. & 5 & 5 & 0 & 0 & 0 \\
\hline 2 & The use of ICT will be easier and effective. & 5 & 5 & 0 & 0 & 0 \\
\hline 3 & The use of ICT will facilitate teacher in delivering materials. & 6 & 4 & 0 & 0 & 0 \\
\hline 4 & The use of ICT will increase students' motivation in learning process. & 2 & 8 & 0 & 0 & 0 \\
\hline 5 & The use of ICT will greatly help students understand the material. & 1 & 7 & 2 & 0 & 0 \\
\hline 6 & I think that ICT helps in bridging communication gap among people. & 0 & 6 & 4 & 0 & 0 \\
\hline 7 & I think that there are many support factors of the use ICT & 1 & 9 & 0 & 0 & 0 \\
\hline 8 & I think that there are many inhibiting factors of the use ICT & 0 & 5 & 3 & 2 & 0 \\
\hline 9 & $\begin{array}{l}\text { Teachers need to provide learning materials for students that can be accessed any } \\
\text { time outside of school hours }\end{array}$ & 2 & 7 & 1 & 0 & 0 \\
\hline 10 & $\begin{array}{l}\text { Teachers need to attend teacher's training and education about the integration of } \\
\text { ICT for improving their professional competence. }\end{array}$ & 4 & 6 & 0 & 0 & 0 \\
\hline & $\begin{array}{c}\text { Total } \\
\text { Total in Percent }\end{array}$ & $\begin{array}{c}26 \\
26 \%\end{array}$ & $\begin{array}{c}62 \\
62 \%\end{array}$ & $\begin{array}{c}10 \\
10 \%\end{array}$ & $\begin{array}{c}2 \\
2 \%\end{array}$ & $\begin{array}{c}\mathbf{0} \\
\mathbf{0} \%\end{array}$ \\
\hline
\end{tabular}

The result of ICT Utilization in mastering teachers' professional competence can be calculated into integrated score. The integrated score was showed in Table 6.

Table 6. Integrated Score of ICT Utilization in Mastering Teachers' Professional Competence

\begin{tabular}{clcc}
\hline No. & \multicolumn{1}{c}{ Statements } & $\begin{array}{c}\text { Integrated } \\
\text { Score }\end{array}$ & Percentage \\
\hline 1 & The use of ICT will improve teacher' professional competence. & 45 & $10,92 \%$ \\
2 & The use of ICT will be easier and effective. & 45 & $10,92 \%$ \\
3 & The use of ICT will facilitate teacher in delivering materials. & 46 & $11,16 \%$ \\
4 & The use of ICT will increase students' motivation in learning process. & 42 & $10,19 \%$ \\
5 & The use of ICT will greatly help students understand the material. & 39 & $9,46 \%$ \\
6 & I think that ICT helps in bridging communication gap among people. & 36 & $8,73 \%$ \\
7 & I think that there are many support factors of the use ICT & 41 & $9,95 \%$ \\
8 & I think that there are many inhibiting factors of the use ICT & 33 & $8,01 \%$ \\
9 & Teachers need to provide learning materials for students that can be accessed & 41 & $9,95 \%$ \\
& any time outside of school hours & 44 & $10,67 \%$ \\
10 & Teachers need to attend teacher's training and education about the integration & 4 & $\mathbf{1 0 0} \%$ \\
& of ICT for improving their professional competence. & $\mathbf{4 1 2}$ & $\mathbf{1 0}$ \\
\end{tabular}

Based on Table 6 , it can be concluded that the highest statement of respondents' ICT utilization in mastering teachers' professional competence was the use of ICT will facilitate teacher in delivering materials. While the lowest statement of respondents' ICT utilization in mastering teachers' professional competence was teacher thinks that there are many inhibiting factors of the use of ICT.

\section{Supporting and inhibiting factors in the ICT utilization}

In this study, there were twelve dimensions and items of supporting and inhibiting factors in the ICT Utilization. The general opinion was about teachers' perception in the ICT Utilization to find supporting and inhibiting factors. The result was presented in the following table.

Table 7. Supporting and Inhibiting Factors in the ICT Utilization

\begin{tabular}{clcccc}
\hline No. & \multicolumn{1}{c}{ Indicators } & A & B & C & D(Optional) \\
\hline 1 & Teachers' understanding about professional competence. & $30 \%$ & $20 \%$ & $50 \%$ & - \\
2 & Teachers do activities to improve teachers' professional & $37,5 \%$ & $31,25 \%$ & $31,25 \%$ & - \\
& competence & $0 \%$ & $0 \%$ & $100 \%$ & - \\
3 & Reason to use ICT in classroom & $50 \%$ & $42,8 \%$ & $7,14 \%$ & - \\
4 & The advantages that teachers get in using ICT & $50 \%$ &
\end{tabular}




\begin{tabular}{clcccc}
\hline 5 & Teachers need ICT in delivering materials & $7,6 \%$ & $76,9 \%$ & $15,3 \%$ & - \\
6 & There still are some teacher who are reluctant in using ICT in & $16,7 \%$ & $50 \%$ & $33,3 \%$ & - \\
& delivering materials & & & \\
7 & Teachers' consideration choose media in classroom learning & $43,75 \%$ & $18.75 \%$ & $37,5 \%$ & - \\
8 & The problems that teachers found in using ICT & $58,3 \%$ & $25 \%$ & 16,7 & - \\
9 & Supporting factors & $45,4 \%$ & $27.3 \%$ & $27,3 \%$ & - \\
10 & Inhibiting factors & $26,7 \%$ & $33,3 \%$ & $33,3 \%$ & $6,7 \%$ \\
11 & A provision that requires in using ICT & $40 \%$ & $60 \%$ & - & - \\
\hline
\end{tabular}

This structured interview discussed eleven dimensions has been observed including teachers' understanding about professional competence, teachers' activities to improve professional competence, reason to use ICT, the advantages of using ICT, teachers' needs in using ICT, there are some teachers who reluctant in using ICT, teachers' consideration in using ICT, the problem that teachers found in using ICT, supporting factors, inhibiting factors, and a provision that requires in using ICT.

The first dimension was teachers' understanding about professional competence. There were $50 \%$ of respondents agreed with the correct answer (professional competence is teachers' ability they have to master learning material deeply, curriculum, management classroom, lesson plan, etc.) $30 \%$ of respondents chose option A and $20 \%$ of them chose option B. It can be concluded that half of respondents have understood about the definition of professional competence. Otherwise $50 \%$ of them did not understand about it.

The next dimension was about teachers' activities to improve professional competence. In this statement, there were three alternative responses about teachers' activities to improve professional competence that were option A; mastering learning materials, option B; using ICT in classroom, and option C; attending teacher's competency training. This structured interview question can be chosen more than one alternative respond by the respondents. Based on the data, there was $37,5 \%$ of respondents agreed with mastering learning materials. $31,25 \%$ of respondents agreed with using ICT in classroom and $31,25 \%$ of respondents agreed with attending teacher's competency training.

The third dimension was about reason to use ICT in classroom. In this statement, there were three alternative responses that were option A; because of teacher's supervision, option B; it is used to utilize teacher's professional competence, and option $\mathrm{C}$; to make teaching and learning process easier. From the data, it can be concluded that $100 \%$ of respondents agreed with option C; reason to use ICT in classroom is to make teaching and learning process easier.

The next dimension was about the advantages of using ICT. In this statement, there were three alternative responses that were option $\mathrm{A}$; to make teaching and learning process easier, option $\mathrm{B}$; to increase student's motivation in learning process, and option $\mathrm{C}$; to improve teacher's professional competence. The respondents also can pick more than one alternative responses because there were many advantages in using ICT in classroom. Based on the data, it can be concluded that $50 \%$ of respondents agreed with option A. $42,8 \%$ of respondents agreed with option B. Then, $7,14 \%$ of respondents agreed with option C.

The further dimension was about teachers' needs of using ICT. In this statement, there were three alternative responses that were option A; to prepare teacher's supervision, option $\mathrm{B}$; to make easier in delivering material, and option $\mathrm{C}$; to take part in digital era. The respondents also can pick more than one alternative response. Based on the data, respondents agreed with option A was 7,6\%. There was $76,9 \%$ of respondents agreed with option B that was to make easier in delivering materials and respondents agreed to take part in digital era was $15,3 \%$.

The sixth dimension was about there are some teachers who are reluctant in using ICT. In this statement, there were three alternative responses that were option A; the lack of facilities, option B; the lack of competence in utilizing ICT, and option C; the lack of motivation in utilizing ICT. Respondents agreed with the lack of facilities was $16,7 \%$. There was $50 \%$ of respondents agreed with the lack of competence in utilizing ICT. Respondents agreed with the lack of motivation in utilizing ICT was $33,3 \%$. It can be concluded that the lack of competence in utilizing ICT was the highest response of why teachers still reluctant of using ICT are.

The further dimension was about teachers' consideration in choosing media to deliver materials. In this statement, there were three alternative responses that were access, cost and facilities. From the data, the respondents can choose more than one response that $43,75 \%$ of respondents agreed with access. $18,75 \%$ of respondents agreed with cost. Then, $37,5 \%$ of respondents agreed with facilities. 
The next dimension was about the problems that teachers found in using ICT. In this statement, there were three alternative responses. They were facility limitations, teacher's unwillingness, and teacher cannot operate media such as computer, social media, etc. based on the data. It can be concluded that $58,3 \%$ of respondents agreed with facility limitations. There were $25 \%$ of respondents agreed with teacher's unwillingness and $16,7 \%$ of respondents agreed with teacher cannot operate media such as computer, social media, etc.

The next dimension was about supporting factor in the ICT utilization. In this statement, there were three alternative responses. They were facilities, teacher's competence and time. Respondents also can write other opinion about supporting factor in the ICT utilization. Based on the data, there were $45,4 \%$ of respondents agreed with facilities. Furthermore, $27,3 \%$ of respondents agreed with teacher's competence. Then, $27,3 \%$ agreed with time. It can be concluded that facilities was the highest response of supporting factors in the ICT utilization.

The further dimension was about inhibiting factor in the ICT utilization. In this statement, there were three alternative responses that were the lack of facilities, the lack of teacher's competence, and the lack of time. Respondents also can write other opinion about inhibiting factor in the ICT utilization. From the data, there were $26,7 \%$ of respondents agreed with the lack of facilities. While $33,3 \%$ of respondents agreed with the lack of teacher's competence and also $33,3 \%$ of respondents agreed with the lack of time. In addition, there was other response that written by respondent that was the lack of access, it was $6,7 \%$.

The last dimension was about a provision that requires in using ICT. There were two alternative responses. Those responses were yes, there is a provision and no, there is no provision. Based on the data, there were $40 \%$ of respondents agreed with there is a provision. On the other hand, $60 \%$ of respondents agreed with this response; there was no provision. The respondents who agreed with there was a provision have some reasons. It can be a provision from the governor and the principal of the school to use ICT in classroom.

\section{Discussion}

This part presented the discussion and answer of the research questions. They were (1) How is teachers' familiarity on the use ICT in classroom learning? (2) How is teachers' professional competence in utilizing ICT in classroom learning? (3) What are supporting and inhibiting factors of teachers' professional competence in utilizing ICT?

Based on the result of the questionnaire and structured interview, it can be concluded that ten English teachers have already utilized ICT in teaching and classroom learning. They were aware of the use of ICT in the classroom having an important role in mastering teacher's professional competence. Even though they still did not know about the definition of ICT and professional competence correctly, but they have already used ICT in the learning process well. This result was in line with the result of the research conducted by Adhini (2018). She presented that fourteen English teachers were able to use social media in the classroom and outside of the class influenced by social media workshops attended by teachers. Fourteen English teachers asserted that they cannot ignore the role of social media in education because social media today plays a key role in developing the quality of education and increasing enrollment across the world.

Next research conducted by Jatileni \& Jatileni (2018), they claimed that Namibian primary school teachers hold positive perceptions towards the use of ICT in teaching and learning. Based on the findings, it can be concluded that ten teachers were familiar in using ICT in classroom learning. They claimed that the use of ICT can help their works in the teaching and learning process. They used media of ICT such as social media, accessing the internet, laptop, computer, etc. They were also ready in the use of ICT in every meeting or once a week/month even though they were ready with the preparation or without preparation. This finding is in line with the research conducted by Budiman et al. (2018). They revealed that the teachers believed that the integrating of ICT in the classroom is crucial. This positive perception of the use of ICT contributes to the ease of ICT integration in learning, as explained by Saeed (2015). He showed that most of the English teachers have positive attitudes towards the use of ICT in teaching English language. When delivering the materials by using ICT, it has greatly enhanced the quality of the outcomes of the lesson taught. ICT is beneficial for both teachers and students as well. It can also motivate students to learn more because of the interesting display provided by ICT in the teaching and learning process. On the other hand, teachers stated that the teacher's role in $21^{\text {st }}$-century learning is merely as facilitators, no 
longer as transmitters. Thus, they also have to take part in this digital era, they should be ICT literate to face the challenge of $21^{\text {st }}$ century learning.

From the data questionnaire, the teacher's professional competence can improve by utilizing ICT in teaching and learning classrooms. It can be testified in Tables 2 and Table 3. ICT utilization such as the use of a computer/laptop was a medium in delivering materials in the classroom, accessing the internet to upload and downloading some tasks given by the teacher. The use of social media is to share some information about the material. The use of ICT also can improve the teacher's professional competence because ICT usage is an easier and effective way to deliver materials. It can facilitate teachers, increase students' motivation, and greatly help students understand the material. In addition, ICT utilization has brought good impacts on teachers' professional competence because of COVID-19 pandemic. Nowadays, teachers were more interesting to master the use of ICT in classroom learning. Furthermore, teachers are required to use ICT in the online classroom. This finding is in line with research conducted by Akinwamide \& Felicia (2018) that ICT was an appropriate medium used in teaching and learning process. ICT is a professional resource, a mode of classroom delivery, and a source of valid and valuable text types.

In the structured interview, there were supporting and inhibiting factors on ICT utilization. Based on the data findings, these were the supporting factors such as making it easier in the teaching and learning process, increasing students' motivation, improving teachers' professional competence, and taking part in the digital era. In addition, the adequate facilities and time were in supporting factors. This finding is in line with the research conducted by Al-Munawwarah (2014). She showed that there were some benefits of ICT utilization; helping teachers to conduct interesting and enjoyable learning activities; promoting learning autonomy; motivating students to learn. Helping teachers to conduct interesting and enjoyable learning activities means that ICT integration helps the teachers to give examples and design interesting teaching materials. They also assumed that by utilizing ICT in English language teaching and learning process helped the teachers to organize interesting and enjoyable learning activities. Promoting learning autonomy means that the use of ICT, particularly web-browser may help teachers to build students' awareness to learn by assisting them to seek various resources related to the materials given. Motivating students to learn means that the materials were taken from online language websites and language programs increased students' motivation to learn since it provided the students with a motivating learning atmosphere to engage in the teaching and learning process.

Otherwise, there were inhibiting factors such as the lack of facilities, the lack of teachers' competence, the lack of time, the lack of motivation, the lack of accessing media of ICT, and lastly teachers' unwillingness. This finding is in line with the research conducted by Al-Munawwarah (2014). She showed that there were some inhibiting factors on the use of ICT; time allocation; technical problems; the strategies used by the teachers to overcome the challenges in using ICT. The teachers mentioned that the lack of time as one of the inhibiting factors in using ICT. They spent more time to check the entire tools and program before using it. If there is something wrong with the tools or programs, they found technical problems in using ICT. The teachers usually found the problems; they faced the lack of internet connection. They faced technical support problems when they were conducting learning process in language laboratory due to some headphones, language programs, and computers which were unusable. They also faced an unexpected situation in the middle of teaching and learning process. For example, the online language websites could not be used because the lack of internet connection. Teachers had the strategies to overcome the challenges in using ICT. They preferred to use downloadable materials including videos and prepared those materials before conducting the teaching and learning process. Moreover, they also prepared to design PowerPoint presentations before entering the classroom. By doing this strategy, they could conduct the learning process more effectively.

According to Suryani (2010), there are some potential benefits of ICT. Those are: by using ICT in teaching and learning classrooms, the students can be active learners, by having access to the internet in their schools, the students will not totally depend on the teachers, the use of blogs, for instance. It can allow the teachers and students to be very up-to-date to the issues and discussion in the educational sector or other sectors, and ICT can also provide a way for dynamic and collaborative learning. Besides dynamic learning, ICT allows all the human components of schools; the principals, administrations, teachers, IT coordinators, and the students to get involved in the collaborative learning and forming learning communities. Learning using ICT is more than learning through memorization. It allows the learners to experience their learning processes, being 
interactive, enjoy, and have fun with technology. ICT also can improve children's literacy. The use of ICT not only can support the cognitive development of the students but also increase their motivation to learn and their interaction in learning. This study is in line with the writer's study that there were supporting factors on the use of ICT in the classroom. The supporting factors were making teaching and learning process easier, increasing students' motivation, improving teachers' professional competence, and taking part in this era.

On the other hand, Suryani (2010) stated the difficulties of ICT; teachers' readiness, school supports, and finance. If the teachers have inadequate preparation in using ICT in the front of their students, they will be afraid. When in the middle of teaching the tools or program of ICT learning cannot operate well, they will be embarrassed. The other factors of teachers' readiness are teachers are not competent due to technical training and insufficient access to technological resources. Teachers do not have sufficient school support and computing educational background/skills. The school supports also include the lack of school leaders (principals). If there is an unsupportive leader, it may impede the successful implementations of ICT. The successful implementation of ICT in developed countries like in Indonesia also can be impeded by insufficient funds. To maintain up-todate technology also need a lot of finance. Some institutions have high finance to support the ICT implementations, other institutions may do not have sufficient finance. This can open up a huge technology gap between the technologically advantaged and disadvantaged institutions.

\section{CONCLUSION}

Based on the findings in the previous chapter, it showed that there were some points as the conclusion of this research. First, ten English teachers were familiar in the use of ICT in classroom learning. They realized that the presence of ICT is able to develop their professional competence.

In addition, there were five indicators that presented information about teacher's familiarity on the use ICT in classroom. They were; teachers' understanding about ICT; ICT classification; teacher's frequency on the use ICT; teacher's readiness in using ICT; and the use ICT can support teacher's professional competence. The first indicator showed that there was only one of ten English teachers who understood the truly meaning of ICT. They were still difficult to distinguish the correct meaning of ICT, social media, and internet in words. However, they have already known about ICT, social media and internet services. Second indicator presented ICT classification that teachers often used in classroom. Accessing internet and using computer or laptop have the same percentage. It meant that most of the teachers preferred to use computers or laptops and access the internet than using social media. Third indicators displayed teacher's frequency on the use ICT. A half of ten teachers used ICT once a week. Three teachers used ICT once a month. Two of the teachers used ICT every meeting. Fourth indicators stated that five teachers were ready to use ICT in classroom learning and they also prepared material and ICT services. Meanwhile, there were two teachers which are not ready to use ICT in classroom. The last indicator reported that four English teachers agreed; the use of ICT always supports their professional competence. On the other hand, the use of

ICT sometimes supports their professional competence was selected by six English teachers.

Second, the ICT utilization in classroom can support teacher's professional competence. Questionnaire was taken to get information about ICT utilization. First questionnaire reported that the ICT utilization could look up teaching materials; the use of ICT made effective time; teachers were more productive; the ICT utilization made preparation of materials easier, etc. Second questionnaire stated that the ICT utilization can improve teachers' professional competence. The teachers believed that ICT services made communication with their students easier. There were also many advantages of the use of ICT such as the ICT utilization can facilitate the teachers in delivering materials; the ICT utilization will be easier and effective; the use of ICT increases students' motivation; the ICT utilization will greatly help students to understand the material; etc.

Third, there were some supporting and inhibiting factors on the use of ICT in classroom learning. The supporting factors were; making easier in teaching and learning process; increasing students' motivation; improving teachers' professional competence; and taking part in digital area. In addition, the facilities and time were in supporting factors. The inhibiting factors were as the lack of facilities, the lack of teachers' competence, the lack of time, the lack of motivation, the lack of accessing media of ICT and teachers' unwillingness. 


\section{ACKNOWLEDGEMENT}

I would like to thank my sincere gratitude to Mr. Arif Suryo Priyatmojo, S.Pd., M.Pd. as the advisor who have led and provided invaluable and continuous guidance, advice, as well as encouragement in making and completing my final project.

\section{REFERENCES}

Adhini. I. N. (2018). Teachers' Perceptions of Social Media in Developing Pedagogical Competence. Final Project. English Department.Faculty of Languages and Arts. Universitas Negeri Semarang.

Akinwamide, T. K., \& Felicia, F. B. K. (2018). Professional updates for language teachers in a digitally infected clime: The ICT utilization sensibility. International Journal of English Language Teaching, 6, 40-48.

Al-Munawwarah, S. F. (2014). Teachers' perceptions on the use of ICT in Indonesian EFL learning context. English Review: Journal of English Education, 3(1), 70-80.

Budiman, A., Rahmawati, R., \& Ulfa, R. A. (2017). Peran teknologi informasi dan komunikasi dalam Pendidikan. Al-Tadzkiyyah: Jurnal Pendidikan Islam, 8, 31-40.

Creswell, J. W. (2014). Research Design: Qualitative, Quantitative and Mixed Methods Approaches (4th ed.). Thousand Oaks, CA: Sage

Di Perto, G. et al.. (2020). The likely impact of COVID-19 on education: Reflections based on the existing literature and international datasets, EUR 30275 EN, Publications Office of the European Union, Luxembourg, ISBN 978-92-76-19937-3, doi:10.2760/126686, JRC121071.

$\mathrm{Fu}$, J. S. (2013). ICT in education: A critical literature review and its implications. International Journal of Education and Development using Information and Communication Technology (IJEDICT), 9, 112-125.

Jatileni, M., \& Jatileni, C. N. (2018). Teachers' perception on the use of ICT in teaching and learning: a case of Namibian primary education. Thesis Philosophical Faculty University of Eastern Finland.

Lao, H. A. E., Kaipatty, G. J., \& Jeronimo, A. D. C. (2017). A study on teachers' competency inteaching English at SMA Negeri 2. 3rd International Seminar on Education and TechnologyISET, 3, 45-50.

Pahrudin, Martono, T., \& Murtini, W. (2016). The effect of pedagogic competency, personality, professional and social competency teacher to study achievement of economic lesson in state senior high school of east Lombok district Academic year 2015/2016. Proceeding the 2nd international conference on teacher training and education, 2, 332-345.

Priyatmojo, A. S., Areni, G. D. K., \& Purwanto, B. (2017). ICT dalam pembelajaran bahasa Inggris. Semarang: Fastindo.

Saeed, Y.B.M. (2015). The effect of using computer technology on English language teachers' performance. SUST Journal of Humanities 16, 1.

Suryani, A. (2010). ICT in education; Its benefits, difficulties, and organizational development issues. Jurnal Sosial Humaniora, $3,1$.

UNESCO. (2020). Covid-19 Impact on Education Data. COVID-19 Education Disruption and Response. The United Nations Educational, Scientific and Cultural Organization, UNESCO. Paris, France. 